\title{
PREVALENCE OF DISABILITY AND ASSOCIATED FACTORS IN THE ELDERLY
}

\author{
Jair Sindra Virtuoso Júnior ${ }^{1}$, Cristiane Alves Martins ${ }^{2}$, Liliane Beatriz Roza ${ }^{3}$, Thais Reis Silva de Paulo, \\ Maria da Conceição Lopes Ribeiro ${ }^{5}$, Sheilla Tribess ${ }^{6}$
}

${ }^{1}$ Ph.D. in Health Sciences. Professor, Graduate Program in Health Care, Universidade Federal do Triângulo Mineiro (UFTM). Uberaba, Minas Gerais, Brazil. E-mail: jair@ef.uftm.edu.br

${ }^{2}$ M.Sc. in Health Care. Professional, Family Health Support Group, Municipal Government of Patos de Minas. Patos de Minas, Minas Gerais, Brazil. E-mail: cristianeam@unipam.edu.br

${ }^{3}$ Master's student. Graduate Program in Health Care at UFTM. Uberaba, Minas Gerais, Brazil. E-mail: lilianeroza@hotmail.com

${ }^{4}$ M.Sc. in Physical Education. Professor, Undergraduate Program in Physical Education at Universidade Federal do Amazonas. Parintins, Amazonas, Brazil. E-mail: thais.reis.silva@hotmail.com

${ }^{5}$ Master's student. Graduate Program in Physical Education at UFTM. Uberaba, Minas Gerais, Brazil. E-mail: seis_seison@ hotmail.com

${ }^{6}$ Ph.D. in Health Sciences. Professor, Graduate Program in Physical Education at UFTM. Uberaba, Minas Gerais, Brazil. E-mail: sheillatribess@yahoo.com.br

\begin{abstract}
The aim of this study was to estimate the prevalence and factors associated with functional disability in the elderly. The cross-sectional design was used with a sample of 624 individuals, between 60 and 96 years of age. In the assessment of the elderly interviews and physical performance tests were used. In the inferential data analysis, the Poisson regression was used, $\mathrm{p} \leq 0.05$. The prevalence of disability was 17.6\% for Basic Activities of Daily Living and 46.3\% for Instrumental Activities of Daily Living. Functional disability for Basic Activities of Daily Living was associated with increasing age, alcohol consumption, depressive symptoms and frailty; the Instrumental Activities of Daily Living were associated with increasing age, illiteracy, multigenerational family arrangement, hospitalization and fragility. The variables that remained in the explanatory model for the decline of functional capacity should be emphasized in proposals for public policies to promote the health of the elderly.
\end{abstract}

DESCRIPTORS: Health of the elderly. Activities of daily living. Geriatric nursing.

\section{PREVALÊNCIA DE INCAPACIDADE FUNCIONAL E FATORES ASSOCIADOS EM IDOSOS}

\begin{abstract}
RESUMO: O objetivo deste estudo foi estimar a prevalência e os fatores associados à incapacidade funcional em idosos. O delineamento transversal foi empregado com amostra de 624 indivíduos com idade entre 60 e 96 anos. Na avaliação dos idosos, foram utilizados entrevista e testes de desempenho físico. Na análise inferencial dos dados, foi utilizada a regressão de Poisson, p $\leq 0,05$. A prevalência de incapacidade funcional foi de 17,6\% para Atividades Básicas da Vida Diária e 46,3\% nas Atividades Instrumentais da Vida Diária. A incapacidade funcional para Atividades Básicas da Vida Diária associou-se ao aumento da idade, consumo de bebidas alcoólicas, sintomatologia depressiva e fragilidade; as Atividades Instrumentais da Vida Diária foram associadas ao avanço da idade, analfabetismo, arranjo familiar multigeracional, hospitalização e fragilidade. As variáveis que permaneceram no modelo explicativo para o declínio da capacidade funcional devem ser enfatizadas na proposição de políticas públicas de promoção à saúde de idosos.
\end{abstract}

DESCRITORES: Saúde do idoso. Atividades cotidianas. Enfermagem geriátrica.

\section{LA PREVALENCIA DE LA DISCAPACIDAD Y LOS FACTORES ASOCIADOS EN LOS ANCIANOS}

RESUMEN: El objetivo fue estimar la prevalencia y los factores asociados a la discapacidad. Se utilizó diseño transversal, con muestra de 624 individuos de edades comprendidas entre 60 a 96 años. En la evaluación fueron utilizados entrevista y pruebas de rendimiento físico. En análisis de datos inferencial se utilizó regresión de Poisson, p $\leq 0,05$. La prevalencia de discapacidad fue 17,6\% para las Actividades Básicas de la Vida Diaria y 46,3\% en las actividades instrumentales de la vida diaria. La incapacidad funcional para Actividades Básicas de la Vida Diaria se asoció con la edad, consumo de alcohol, síntomas depresivos y fragilidad; actividades instrumentales de la vida diaria se asociaron con la edad, analfabetismo, disposición de la familia multigeneracional, hospitalización y fragilidad. Las variables que se mantuvieron en el modelo explicativo de la disminución de la capacidad funcional deben hacerse hincapié en la elaboración de políticas públicas para promover la salud de los ancianos.

DESCRIPTORES: Salud del anciano. Actividades cotidianas. Enfermería geriátrica. 


\section{INTRODUCTION}

For decades, population aging has been a reality in developed and developing countries. ${ }^{1}$ In Brazil, the reduced fecundity has resulted in the reduction of the population growth, and the drop in childhood mortality rates and the increased life expectancy have favored the enlargement of the elderly population. ${ }^{2}$

The increased life expectancy and population growth happen rapidly, which hampers the organization of public sectors for elderly care and the encouragement of public policies that allow the human being to age independently and with quality. ${ }^{3}$

For decades, the Brazilian age pyramid, has had a wide base and a narrow tip, indicating a larger number of children and young people. Today, it demonstrates characteristics of a balance among the age group, tending towards a wider tip. This trend towards the inversion of the age pyramid in the country has enhanced an increase in the number of experts in different professional areas who are interested in working with the elderly public. In health, the preservation of the functional capacity has been focused on.

The functional capacity reflects human beings' condition to remain independent for the activities of daily living. The people affected by disabling processes are limited to doing activities related to the social functions. ${ }^{4-5}$ Thus, the elderly loses the condition to communicate and a range of clinical diseases and behavioral problems emerge and are aggravated. ${ }^{5}$

Although some studies indicate factors associated with functional disability, the results of these surveys, like any other studies, are limited in terms of generalization, due to the particularities of the populations (population size, sociocultural aspects, among others). ${ }^{6-8}$ In this research, the characteristics of the place of study are similar to severe Latin American cities with between 200 and 400 thousand inhabitants, implying the generalizability of the results, keeping in mind the social and economic differences. ${ }^{9-11}$ In addition, the health conditions should be continuously monitored to support permanent health promotion policies.

The objective in this study was to estimate the prevalence and the sociodemographic, selfreferred health, clinical and behavioral factors associated with functional disability for basic and instrumental activities of daily living in the elderly.

\section{METHODS}

This research is part of the Population Survey of Physical Exercise and Aging (Epafe), a crosssectional research that involves elderly people aged 60 years or older, male and female, living in the urban region of the city of Uberaba-MG, and was undertaken between May and August 2010.

To determine the sample size, the procedures for finite populations were adopted. ${ }^{12}$ In this calculation, a 5\% significance level was adopted (corresponding to a 95\% confidence interval, $\mathrm{z}$ [a]/2=1.96) and a tolerable sampling error of $3 \%$, resulting in a minimum sample of 490 subjects. To this initial estimated sample size, $20 \%$ was added to explore adjusted associations between the independent variables and functional disability, besides $10 \%$ to compensate for occasional losses, totaling a necessary sample of 647 elderly.

Among the elderly drafted, 23 people did not participate in the study (address not found, refusal to participate in the assessment, partial interview). Thus, the final study sample consisted of 624 elderly (218 men and 406 women), aged 60 years or older, randomly selected from an address database and representing the urban region of the city, proportional per district, family health team and sex.

The population sample consisted of elderly people without symptoms of mental confusion and hearing or sight problems, which would make the assessment more difficult. This assessment was subjective, involving the interviewer's perception of the interviewee's disperse discourse. Besides these aspects, any elderly in a wheelchair, whether temporary or permanently, or who showed sequelae of a stroke, including local loss of strength, were also excluded from the sample.

To assess the participants, trained health professionals individually applied multidimensional interviews, addressing sociodemographic, clinical health and behavioral aspects.

The sociodemographic aspects are related to age, sex, years of education, marital status, current occupation, family arrangement and family income (minimum wages). The clinical health aspects refer to reported diseases (arterial hypertension, cerebrovascular accident (CVA), respiratory problems, back pain, osteoporosis, diabetes, labyrinthitis), number of drugs for continuous treatment, hospitalizations in the last six months, falls in the last 12 months, consumption of alcoholic beverages (once per week), cognitive 
performance assessed through the Mini Mental State Examination (MMSE), ${ }^{13}$ depressive symptoms assessed by using the Geriatric Depression Scale (GDS-15). ${ }^{14}$

The functional disability, operated as a dependent variable in this study, was assessed based on the limitations in Basic Activities of Daily Living (BADL), defined by means of the Katz index, which investigates self-care activities like bathing, grooming, toileting, transferring, eating and continence. ${ }^{15}$ The limitations in Instrumental Activities of Daily Living were assessed using the Brazilian version of the Lawton and Brody scale, considering activities like using the telephone, using transportation, shopping, preparing food, housekeeping, handling medications and handling finances. ${ }^{16}$

For each activity of daily living assessed, three alternative answers were proposed, related to the categories independence ( 2 points), need for partial help (1 point) and need for total help/ unable to do the activity ( 0 points). Thus, elderly who did not need partial or total help on any of the investigated activities for BADL and elderly who scored 11 points or higher for IADL were considered to be independent.

In the behavioral aspect, the habitual physical exercise level was analyzed using the International Physical Activity Questionnaire (IPAQ), adapted for elderly people. ${ }^{17}$ The IPAQ includes questions related to the physical exercise done in a common week, of moderate to strong intensity, taking at least 10 continuous minutes, distributed in four domains of physical exercise: work, transportation, housework and leisure/ recreation. The classification criterion employed followed the international recommendations, in which individuals who spent less than $150 \mathrm{~min}-$ utes/week on physical exercise were considered insufficiently active. ${ }^{18}$

Frailty, a latent variable that combines physical performance, clinical health and behavioral aspects, was measured using the adapted version of Fried et al., ${ }^{19}$ but the operation of some dimensions was adapted to the Brazilian context. Frailty was identified based on the presence of three or more of the five components examined: (1) reduction of grip strength in dominant hand, measured using a dynamometer and adjusted for sex and body mass index (BMI); (2) unintentional weight loss greater than $5 \%$ of the body weight in the previous year; (3) reported "exhaustion", assessed through the question "do you feel full of energy?" on the Geriatric Depression Scale (GDS-15); ;4 (4) functional limitation to get up from a chair, assessed based on the elderly's inability to get up from the chair five times without help from the arms; and (5) low level of physical exercise ( $<150 \mathrm{~min} /$ week). ${ }^{18}$

To analyze the data, descriptive (mean, standard deviation and absolute and relative frequencies) and inferential statistical procedures were used, including gross and adjusted analyses, using Poisson's regression. Departing from the strategy of associations between the dimensions studied, three explanatory models were elaborated, introducing the variables in the form of blocks. Block 1 contains the sociodemographic conditions (age, years of education, current occupation, marital status, family income and family arrangement); block 2, self-referred health variables (self-referred illnesses, hospitalization, falls, medication use, smoking, alcohol consumption); block 3, clinical and behavioral variables (cognitive deficit, depression symptoms, physical exercise and frailty). A significance level of $\mathrm{p} \leq 0.05$ was considered and a $95 \%$ confidence interval $(\mathrm{CI})$, calculating the adjusted prevalence ratios (PR). The data were analyzed using the software Statistical Package for the Social Sciences (SPSS), version 15.0.

This research followed the ethical principles of the Helsinki Declaration and the standards of the National Health Council. The research protocols received Institutional Review Board approval at Universidade Federal do Triângulo Mineiro (Opinion 1521/2009).

\section{RESULTS}

The age of the 624 subjects $(65.1 \%$ female and $34.9 \%$ male) ranged between 60 and 96 years, with a mean age of 71 years $(\mathrm{SD}=7.77)$. Most of the elderly are married or live with a partner $(52.7 \%)$, live in multigenerational homes $(54.8 \%)$, specifically bigenerational ( $30.6 \%$, grand parents and children), low education level, considering that $40.3 \%$ have two years of education at most, $19.1 \%$ of whom are illiterate; $72.8 \%$ are retired or pensioners, with a low monthly income, as $51.5 \%$ survived on up to two minimum wages ( $\mathrm{R} \$ 1,020.00)$.

The assessment of the elderly people's functional capacity showed that $17.6 \%(n=110)$ were dependent for BADL and that $46.3 \%(n=289)$ were moderate to severely dependent for IADL.

Detailed information on the sociodemographic characteristics, regarding the clinical and 
behavioral aspects, distinguished by sex, have been published earlier. ${ }^{22}$

As the factors associated with the functional disability for the basic and instrumental activities were similar between the sexes, the analyses were presented for the total sample.

The gross and adjusted prevalence ratio (PR) for independent variables of functional disability in BADL and IADL are displayed in tables 1 and 2 .

Table 1 - Gross and adjusted prevalence ratios for independent variables with regard to functional disability for Basic Activities of Daily Living in elderly people. Uberaba-MG, 2010

\begin{tabular}{|c|c|c|c|c|c|}
\hline \multirow{3}{*}{ Variables } & \multicolumn{5}{|c|}{ Disability BADL } \\
\hline & \multirow{2}{*}{$\begin{array}{c}\text { Prevalence } \\
\% \\
\end{array}$} & \multicolumn{2}{|c|}{ Gross analysis } & \multicolumn{2}{|c|}{ Adjusted analysis } \\
\hline & & PR $(95 \% \mathrm{CI})$ & p & PR (95\% CI) & $\mathbf{p}$ \\
\hline \multicolumn{6}{|c|}{ Block 1: sociodemographic conditions } \\
\hline Age (years) & & 1.05 [1.03-1.07] & 0.000 & 1.03 [1.00-1.05] & 0.037 \\
\hline \multicolumn{6}{|l|}{ Current occupation } \\
\hline Worker/retired worker & 10.0 & 1 & \multirow{2}{*}{0.007} & 1 & \multirow{2}{*}{0.148} \\
\hline Retired/pensioner & 20.5 & $2.05[1.22-3.44]$ & & $1.50[0.87-2.61]$ & \\
\hline \multicolumn{6}{|l|}{ Marital status } \\
\hline Single/ divorced/separated & 9.6 & 1 & \multirow{3}{*}{0.001} & 1 & \multirow{3}{*}{0.125} \\
\hline Married/living with partner & 15.1 & $1.58[0.78-3.20]$ & & $1.55[0.76-3.14]$ & \\
\hline Widowed & 27.2 & 2.84 [1.39-5.79] & & & \\
\hline \multicolumn{6}{|c|}{ Block 2: self-referred health variables ${ }^{\dagger}$} \\
\hline \multicolumn{6}{|c|}{ Hospitalization } \\
\hline No & 16.0 & 1 & \multirow{2}{*}{0.020} & 1 & \multirow{2}{*}{0.510} \\
\hline Yes & 27.2 & $1.70[1.09-2.66]$ & & $1.17[0.74-1.86]$ & \\
\hline \multicolumn{6}{|l|}{ Fall } \\
\hline No & 13.0 & 1 & \multirow{2}{*}{0.000} & 1 & \multirow{2}{*}{0.003} \\
\hline Yes & 28.6 & $2.21[1.52-3.21]$. & & $1.78[1.21-2.60]$ & \\
\hline \multicolumn{6}{|l|}{ Arterial hypertension } \\
\hline No & 11.6 & 1 & \multirow{2}{*}{0.008} & 1 & \multirow[t]{2}{*}{0.461} \\
\hline Yes & 21.1 & $1.82[1.17-2.83]$ & & 1.20 [0.74-1.96] & \\
\hline \multicolumn{6}{|l|}{ Cerebrovascular accident } \\
\hline No & 16.4 & 1 & \multirow{2}{*}{0.017} & 1 & \multirow[t]{2}{*}{0.313} \\
\hline Yes & 31.4 & 1.91 [1.13-3.25] & & 1.33 [0.77-2.29] & \\
\hline Respiratory problems & & & & & \\
\hline No & 16.4 & 1 & 0026 & 1 & \\
\hline Yes & 29.0 & $1.77[1.07-2.94]$ & $0.0 \angle 0$ & $1.35[0.80-2.28]$ & 0.263 \\
\hline Back pain & & & & & \\
\hline No & 13.5 & 1 & 0071 & 1 & \\
\hline Yes & 21.3 & 1.58 [1.07-2.33] & 0.021 & 1.29 [0.84-1.97] & 0.242 \\
\hline Osteoporosis & & & & & \\
\hline No & 14.5 & 1 & 0001 & 1 & \\
\hline Yes & 28.2 & 1.94 [1.35-2.86] & 0.001 & $1.35[0.88-2.06]$ & 0.173 \\
\hline Diabetes & & & & & \\
\hline No & 15.8 & 1 & & 1 & \\
\hline Yes & 24.8 & $1.57[1.03-2.37]$ & 0.034 & $1.31[0.85-2.02]$ & 0.230 \\
\hline Labyrinthitis & & & & & \\
\hline No & 14.9 & 1 & م 0010 & 1 & \\
\hline Yes & 24.7 & 1.66 [1.13-2.43] & 0.010 & 1.09 [0.72-1.65] & 0.689 \\
\hline Alcohol use & & & & & \\
\hline No & 20.6 & 1 & ב002 & 1 & 0009 \\
\hline Yes & 7.2 & $0.35[0.18-0.67]$ & 0.002 & $0.42[0.22-0.81]$ & 0.009 \\
\hline
\end{tabular}

Medication 


\begin{tabular}{|c|c|c|c|c|c|}
\hline \multirow{3}{*}{ Variables } & \multicolumn{5}{|c|}{ Disability BADL } \\
\hline & \multirow{2}{*}{$\begin{array}{c}\text { Prevalence } \\
\%\end{array}$} & \multicolumn{2}{|c|}{ Gross analysis } & \multicolumn{2}{|c|}{ Adjusted analysis } \\
\hline & & PR $(95 \% \mathrm{CI})$ & $\mathrm{p}$ & PR $(95 \%$ CI $)$ & $\mathbf{p}$ \\
\hline 0 medication & 6.1 & 1 & & 1 & \\
\hline 1 to 2 drugs & 12.4 & $2.02[0.84-4.90]$ & & $1.24[0.47-3.17]$ & \\
\hline 3 to 4 drugs & 21.9 & $3.58[1.52-8.45]$ & 0.000 & $1.91[0.74-4.92]$ & 0.194 \\
\hline$\geq 5$ drugs & 29.2 & $4.77[2.02-11.29]$ & & $2.02[0.76-5.37]$ & \\
\hline \multicolumn{6}{|c|}{ Block 3: clinical and behavioral variables ${ }^{\ddagger}$} \\
\hline \multicolumn{6}{|c|}{ Cognitive deficit } \\
\hline Absence & 15.2 & 1 & \multirow{2}{*}{0.002} & 1 & \multirow{2}{*}{0.597} \\
\hline Presence & 29.5 & $1.94[1.28-2.94]$ & & $1.13[0.72-1.75]$ & \\
\hline \multicolumn{6}{|l|}{ Depressive symptoms } \\
\hline Absence & 11.5 & 1 & \multirow{2}{*}{0.000} & 1 & \multirow{2}{*}{0.028} \\
\hline Presence & 28.0 & $2.44[1.69-3.57]$ & & $1.60[1.05-2.44]$ & \\
\hline \multicolumn{6}{|l|}{ Physical exercise } \\
\hline Sufficiently active & 11.5 & 1 & \multirow{2}{*}{0.000} & 1 & \\
\hline Insufficiently active & 28.6 & $2.48[1.70-3.63]$ & & $1.19[0.72-1.94]$ & 4.99 \\
\hline \multicolumn{6}{|l|}{ Frailty } \\
\hline Non frail & 6.4 & 1 & \multirow{3}{*}{0.000} & 1 & \multirow{3}{*}{0.05} \\
\hline Pre-frail & 16.8 & 2.63 [1.40-4.92] & & $1.92[0.98-3.76]$ & \\
\hline Frail & 37.1 & $5.81[3.08-10.9]$ & & 2.77 [1.22-6.29] & \\
\hline
\end{tabular}

*Adjusted for the block of sociodemographic variables; $\uparrow$ Adjusted for the blocks of sociodemographic and self-referred health variables; $\ddagger$ Adjusted for the blocks of sociodemographic conditions, self-referred health and clinical and behavioral variables.

In the gross analysis for the BADL, the functional disability was associated with age, marital status, current occupation, hospitalization, falls, hypertension, CVA, respiratory problems, back pain, osteoporosis, diabetes, labyrinthitis, alcohol consumption, number of drugs, cognitive deficit, depressive symptoms, physical exercise and frail- ty. When the analysis was adjusted onblock 1 , sociodemographic conditions; block 2, self-referred health variables; and block 3 , clinical conditions, respectively, aging, history of falls, alcohol consumption, presence of depressive symptoms and the frailty syndrome remained associated with the functional disability.

Table 2 - Gross and adjusted prevalence ratios for independent variables with regard to functional disability for Instrumental Activities of Daily Living in elderly people. Uberaba-MG, 2010

\begin{tabular}{|c|c|c|c|c|c|}
\hline \multirow{3}{*}{ Variables } & \multicolumn{5}{|c|}{ Functional disability IADL } \\
\hline & \multirow{2}{*}{$\begin{array}{c}\text { Prevalence } \\
\%\end{array}$} & \multicolumn{2}{|c|}{ Gross analysis } & \multicolumn{2}{|c|}{ Adjusted analysis } \\
\hline & & PR $(95 \%$ CI $)$ & $\mathbf{p}$ & PR $(95 \%$ CI) & $\mathrm{p}$ \\
\hline \multicolumn{6}{|c|}{ Block 1: sociodemographic conditions * } \\
\hline Age (years) & & $1.05[1.03-1.06]$ & 0.000 & $1.03[1.02-1.05]$ & 0.000 \\
\hline \multicolumn{6}{|l|}{ Years of study } \\
\hline Literate & 41.6 & 1 & \multirow{2}{*}{0.000} & 1 & \multirow{2}{*}{0.021} \\
\hline Illiterate & 66.4 & 1.60 [1.23-2.07] & & 1.37 [1.05-1.79] & \\
\hline \multicolumn{6}{|l|}{ Family arrangement } \\
\hline Lives alone & 25.7 & 1 & \multirow{4}{*}{0.032} & 1 & \\
\hline Partner or other & 45.2 & $1.76[1.08-2.88]$ & & 1.99 [1.21-3.28] & \multirow{3}{*}{0.025} \\
\hline + Children & 49.7 & $1.94[1.18-3.17]$ & & $2.16[1.31-3.55]$ & \\
\hline + Grandchildren & 53.6 & $2.09[1.27-3.44]$ & & $2.03[1.22-3.37]$ & \\
\hline \multicolumn{6}{|l|}{ Marital status } \\
\hline Single/ divorced/separated & 23.4 & 1 & \multirow{3}{*}{0.001} & 1 & \multirow[t]{3}{*}{0.107} \\
\hline Married/living with partner & 47.6 & $2.04[1.31-3.17]$ & & $1.62[1.03-2.56]$ & \\
\hline Widowed & 56.1 & $2.40[1.51-3.81]$ & & $1.60[0.99-2.60]$ & \\
\hline
\end{tabular}

Block 2: self-referred health variables $†$

Hospitalization 


\begin{tabular}{|c|c|c|c|c|c|}
\hline \multirow{3}{*}{ Variables } & \multicolumn{5}{|c|}{ Functional disability IADL } \\
\hline & \multirow{2}{*}{$\begin{array}{c}\text { Prevalence } \\
\%\end{array}$} & \multicolumn{2}{|c|}{ Gross analysis } & \multicolumn{2}{|c|}{ Adjusted analysis } \\
\hline & & PR $(95 \% \mathrm{CI})$ & p & PR $(95 \% \mathrm{CI})$ & $p$ \\
\hline No & 42.9 & 1 & \multirow{2}{*}{0.002} & 1 & \multirow{2}{*}{0.020} \\
\hline Yes & 66.3 & 1.55 [1.17-2.05] & & $1.41[1.06-1.88]$ & \\
\hline \multicolumn{6}{|l|}{ Use of alcoholic beverage } \\
\hline No & 49.5 & 1 & \multirow{2}{*}{0.031} & 1 & \multirow{2}{*}{0.254} \\
\hline Yes & 35.3 & $0.71[0.52-0.97]$ & & $0.83[0.61-1.14]$ & \\
\hline \multicolumn{6}{|l|}{ Medication } \\
\hline Quantity consumed & & 1.08 [1.03-1.13] & 0.001 & $1.047[1.0-1.10]$ & 0.076 \\
\hline \multicolumn{6}{|c|}{ Block 3: clinical and behavioral variables $\ddagger$} \\
\hline \multicolumn{6}{|c|}{ Depressive symptoms } \\
\hline Absence & 41.1 & 1 & \multirow{2}{*}{0.013} & 1 & \multirow{2}{*}{0.348} \\
\hline Presence & 55.2 & 1.34 [1.07-1.69] & & $1.13[0.88-1.46]$ & \\
\hline \multicolumn{6}{|l|}{ Cognitive deficit } \\
\hline Absence & 42.2 & 1 & \multirow{2}{*}{0.001} & 1 & \multirow{2}{*}{0.627} \\
\hline Presence & 66.7 & 1.58 [1.21-2.07] & & $1.08[0.80-1.44]$ & \\
\hline \multicolumn{6}{|l|}{ Frailty } \\
\hline Non frail and pre-frail & 37.3 & 1 & \multirow{2}{*}{0.000} & 1 & \multirow{2}{*}{0.002} \\
\hline Frail & 82.3 & $2.20[1.73-2.80]$ & & 1.56 [1.17-2.07] & \\
\hline
\end{tabular}

*Adjusted for the block of sociodemographic variables; $\uparrow$ Adjusted for the blocks of sociodemographic and self-referred health variables; $\ddagger$ Adjusted for the blocks of sociodemographic conditions, self-referred health and clinical and behavioral variables.

For the instrumental activities, the gross analysis showed a significant association between functional disability and age, years of education, family arrangement, marital status, history of hospitalization, alcohol consumption, number of drugs, cognitive deficit, depressive symptoms and frailty. After the analysis adjusted for blocks, the variables that remained associated with the functional disability for IADL were aging, illiteracy, multigenerational family arrangement, hospitalization history and frailty syndrome.

\section{DISCUSSION}

This research provided general information on functional disability for basic and instrumental activities of daily living in a population sample of non-institutionalized Brazilian elderly.

The characteristics of the study participants are similar to other population surveys of elderly people's health in Latin American countries. ${ }^{9-11}$ This fact strengthens the potential to generalize the results presented here and, similarly, permits further knowledge on functional capacity in hardly distinguished social and demographic contexts.

The prevalence found for functional disability for BADL $(17.6 \%)$ is similar to the results in other Brazilian studies, undertaken in the Northeast, South and Southeast, showing that more than half of the elderly were totally independent for the BADL. ${ }^{6-7,20}$ The prevalence of functional disability for IADL corresponded to $46.3 \%$ though, a result that differs from other Brazilian studies. ${ }^{6,20}$

The range of questionnaires used to measure the functional capacity and the different cut-off points adopted to classify the functional dependence make it difficult to compare the prevalence rates for the basic and instrumental activities. Nevertheless, the markers used in the studies to identify the disabling processes are similar among the studies.

The functional capacity reflects the condition of independence for daily activities. The American Geriatrics Society recommends a classification model with three hierarchical levels, in which the advanced activities of daily living (AADL) appear at the top level, corresponding to the activities with greater social interaction, followed by the IADL, until the BADL, corresponding to the lowest level in this ranking. People facing difficulties to develop basic activities of daily living are in more vulnerable health conditions and need care and rapid interventions to avoid mortality. ${ }^{21}$

In this study, the functional capacity classification levels of BADL and IADL were chosen, as the measuring of advanced activities of daily living has been hardly explored in disability prevalence research. ${ }^{22}$ Identifying the most prevalent factors of disability to perform activities of daily living supports the elaboration of interventions that effectively preserve the elderly's functional independence. 
Sociodemographic variables tend to be related to the functional loss process. ${ }^{6-8}$ Among these variables, in this study, the age marker remained in the explanatory model for functional disability in BADL as well as IADL.

Although age is a simple marker for the elderly's health condition, it is commonly present in studies that identify factors associated with functional disability. ${ }^{4,6-7}$ Advanced age cannot be neglected, as it truly is not a synonym of functional disability, but signals a more vulnerable organic structure to the development of disabling processes. ${ }^{23}$

Being widowed represents a state of solitude, involving the loss of a loved one, which entails consequences for the disabling processes. ${ }^{7}$ In the ranked model though, this variable overlapped with depressive symptoms. The current occupation is another variable that did not remain in the final explanatory model as, although the condition of being retired or being a pensioner represents a higher prevalence of functional disability, it did not remain in the ranked model when the clinical health conditions were added.

Alcohol consumption offered protective effects for the presence of disabilities to perform BADL. Although alcohol consumption is harmful to people's health, ${ }^{24}$ in some situations and quantities, the alcohol consumption habit can be related to greater participation in social activities and better functional conditionsl. ${ }^{25}$ In this study, the variable did not remain in the final model though.

Among the reported health problems, only the occurrence of falls and the presence of depressive symptoms remained in the final model as, due to the inclusion of the elderly's frailty condition, other clinical health and behavioral variables did not remain in the final explanatory model.

Falls in elderly over 65 years of age correspond to about $30 \%$, leading to possible fractures and risk of death, besides the fear of falling, restrictions in physical exercise, health decline and increased risk of institutionalization. ${ }^{24}$ The limitations in people's transportation negatively affect their communication and favor social isolation, facts that trigger depressive symptoms. ${ }^{4}$

The continuation of the hospitalization variable represents the presence of some clinical condition, while frailty represents the elderly's state of vulnerability, as a parameter that combines markers related to the functional limitations, a condition that precedes the functional disability, as well as to behaviors related to physical exercise and to the nutritional status.
The hospitalized elderly are more susceptible to losses in the nutritional status due to the reduction in food consumption, disease or medicationrelated food intolerance and inability to prepare one's own meals, which can lead to malnutrition and compromise the functional capacity. ${ }^{26}$

The functional disability for the IADL was similar for the BADL. Nevertheless, in the final explanatory model, besides age, illiteracy and multigenerational arrangements continued. As the IADL represent activities that picture the social function of the home as a link with the community, the low education level ended up influencing the low purchasing power for shopping, the control of finances and other IADL. ${ }^{7}$

On the other hand, in families with multigenerational arrangements, the elderly are more easily deprived of daily activities that are necessary to maintain their functional independence. ${ }^{27}$

Some limitations were verified in this study: 1) the cross-sectional design negatively affects advances in temporal analyses of the factors studied, due to the reverse causality bias, so that no causal relation can be found; 2) use of the questionnaire (measuring of functional disability and other confounding variables through a construct) can underestimate or overestimate some information found; 3) the different research instruments and parameters used to classify the elderly's functional capacity beyond the cut-off point make it difficult to compare the results with other studies.

On the other hand, the possibility of a selection bias is reduced as the sample represents the region studied. In addition, epidemiological studies with cross-sectional designs are important for the sake of public policy development, as they provide rapid information that helps to monitor people's health conditions.

\section{CONCLUSION}

The prevalence of functional disability corresponded to $17.6 \%$ for BADL and $46.3 \%$ for IADL. After the regression analyses using ranked models, the variables that remained in the explanatory model of the functional disability process were aging, falls, alcohol consumption, depressive symptoms and the frailty syndrome for BADL; and aging, illiteracy, multigenerational family arrangement, hospitalizations and the syndrome for IADL.

The variables that remained in the theoretical explanatory model for declined functional capacity 
should be emphasized in the proposal of public health promotion policies aimed at elderly people.

\section{REFERENCES}

1. Thun MJ, DeLancey JO, Center MM, Jemal A, Ward EM. The global burden of cancer: priorities for prevention. Carcinogenesis. 2010 Jan; 31(1):100-10.

2. Mendes Ada C, Sá DA, Miranda GM, Lyra TM, Tavares RA. The public healthcare system in the context of Brazil's demographic transition: current and future demands. Cad Saude Publica 2012 May; 28(5):955-64.

3. Haughton B, Stang J. Population risk factors and trends in health care and public policy. J Acad Nutr Diet. 2012 Mar; 112(3 Suppl):S35-46.

4. Benka J, Nagyova I, Rosenberger J, Calfova A, Macejova Z, Lazurova I, et al. Social support as a moderator of functional disability's effect on depressive feelings in early rheumatoid arthritis: a four-year prospective study. Rehabil Psychol. 2014 Feb; 59(1):19-26.

5. Zimmer Z, Martin LG, Jones BL, Nagin DS. Examining late-life functional limitation trajectories and their associations with underlying onset, recovery, and mortality. J Gerontol B Psychol Sci Soc Sci. 2014 Mar; 69(2):275-86.

6. Pereira GN, Bastos GA, Del Duca GF, Bós AJ. Socioeconomic and demographic indicators associated with functional disability in the elderly. Cad Saude Publica 2012 Nov; 28(11):2035-42.

7. Virtuoso Júnior JS, Guerra RO. Functional incapacity among low-income elderly women. Ciênc Saúde Coletiva 2011 May; 16(5):2541-8.

8. Gupta P, Mani K, Rai SK, Nongkynrih B, Gupta SK. Functional disability among elderly persons in a rural area of Haryana. Indian J Public Health. 2014 Jan-Mar; 58(1):11-6.

9. Muñoz AM, Falque-Madrid L, Zambrano RCH, Maestre GE. Basic anthropometry and health status of elderly: findings of the Maracaibo aging study. J Aging Health 2010 Mar; 22(2):242-61.

10. González-González C, Sánchez-García S, JuárezCedillo T, Rosas-Carrasco O, Gutiérrez-Robledo LM, García-Peña C. Health care utilization in the elderly Mexican population: Expenditures and determinants. BMC Public Health [online]. 2011 [acesso 2014 Mar 05]; 11:192. Disponível em: http:/ / www.ncbi.nlm.nih.gov/pmc/articles / PMC3073904/pdf/1471-2458-11-192.pdf

11. Barbosa AR, Munaretti DB, Coqueiro RS, Borgatto AF. Anthropometric indexes of obesity and hypertension in elderly from Cuba and Barbados. J Nutr Health Aging 2011 Jan;15(1):17-21.

12. Luiz RR, Magnanini MF. The logic of sample size determination in epidemiological research. Cad
Saúde Colet. 2000 Aug-Dec; 8(2):9-28.

13. Almeida OP. The Mini-Mental State Examination and the Diagnosis of Dementia in Brazil. Arq NeuroPsiquiatr. 1998 Sept;56(3B):605-12.

14. Almeida OP, Almeida AS. Reliability of the Brazilian version of the Geriatric Depression Scale (GDS) short form. Arq Neuro-Psiquiatr. 1999 Jun; 57(2B):421-6.

15. Lino VTS, Pereira SRM, Camacho LAB, Ribeiro Filho ST, Buksman S. Cross-cultural adaptation of the Independence in Activities of Daily Living Index (Katz Index). Cad Saúde Pública 2008 Jan; 24(1):103-112.

16. Santos RL, Virtuoso-Júnior JS. Reliability of the Brazilian version of the Scale of Instrumental Activities of Daily Living. RBPS 2008 Oct-Dec; 21(4):290-6.

17. Benedetti TRB, Mazo GZ, Barros MVG. Application of the International Physical Activity Questionnaire (IPAQ) for evaluation of elderly women: concurrent validity and test-retest reprodutibility. Rev Bras Ciênc Mov. 2004 Jan-Mar; 12(1):25-34.

18. Haskell WL, Lee IM, Pate RR, Powell KE, Blair SN, Franklin BA, et al. Physical activity and public health: updated recommendation for adults from the American College of Sports Medicine and the American Heart Association. Circulation. 2007 Aug; 116(9):1081-93.

19. Fried LP, Tangen CM, Walston J, Newman AB, Hirsch C, Gottdiener J, et al. Frailty in older adults: evidence for a phenotype. J Gerontol A Biol Sci Med Sci. 2001 Mar; 56(3):M146-56.

20. Tavares DMS, Dias FA. Functional capactiy, morbidities and quality of life of the elderly. Texto Contexto Enferm [online]. 2012 Jan-Mar [acesso 2014 Jun 02]; 21(1):112-20. Disponível em: http:/ / www.scielo.br/scielo.php?pid=S010407072012000100013\&script=sci_arttext\&tlng=en

21. Reuben DB, Solomon DH. Assessment in geriatrics. Of caveats and names. J Am Geriatr Soc. 1989 Jun; 37(6):570-2.

22. Virtuoso-Júnior JS, Tribess S, Paulo TR, Martins CA, Romo-Perez V. Physical activity as an indicator of predictive functional disability in elderly. Rev Latino-Am Enfermagem 2012 Mar-Apr; 20(2):259-65.

23. Tribess S, Virtuoso-Júnior JS, Silva CAR, Paulo TRS, Romo-Perez V, Oliveira RJ. The age marker as a predictive indicator for frailty syndrome in the elderly. Acta Sci Health Sci 2013 Jul-Dec; 35(2):273-7.

24. Tsubota-Utsugi M, Ito-Sato R, Ohkubo T, Kikuya M, Asayama K, Metoki H, et al. Health behaviors as predictors for declines in higher-level functional capacity in older adults: the Ohasama study. J Am Geriatr Soc. 2011 Nov; 59(11):1993-2000.

25. Nieminen T, Prättälä R, Martelin T, Härkänen T, Hyyppä MT, Alanen E, et al. Social capital, health behaviours and health: a population-based 
associational study. BMC Public Health [online]. 2013 [acesso 2014 Jun 02]; 13:613. Disponível em: http:/ / www.ncbi.nlm.nih.gov/pmc/articles / PMC3722011/pdf/1471-2458-13-613.pdf

26. Amrein K, Quraishi SA, Litonjua AA, Gibbons FK, Pieber TR, Camargo CA Jr, et al. Evidence for a U-shaped relationship between prehospital vitamin D status and mortality: a cohort study. JClin Endocrinol Metab. 2014 Apr; 99(4):1461-9.

27. Santos GS, Cunha ICKO. Functional capacity of the elderly seen in a basic health unit in the city of São Paulo. REAS. 2013 May; 2(3):67-76. 